\title{
Dynamics Across Borders in Literature, Theatre, and the Humanities. Foreword
}

DOI: 10.7592/methis.v17i21/22.14581

Good research and publication ideas often come on the spur of the moment, and spontaneity gives energy to longer processes. This joint Special Issue of Methis was sparked by editor-in-chief Marin Laak's idea on the last day of a recent collaborative conference, who was gladly joined by the conference organizer, Władystaw Witalisz.

The present volume is a result of the transdisciplinary conference "Across Borders: Cultures in Dialogue" co-organised by the Estonian Literary Museum and Państwowa Wyższa Szkoła Zawodowa im. St. Pigonia w Krośnie (Krosno State College) in Tartu on 27-29 April 2017. It was the $7^{\text {th }}$ conference of the series and it brought together international scholars working on culture, literature, linguistics, folklore, communication, humour studies, translation and interpreting. The general focus of the "Across Borders" conferences has always been the dynamics of contacts between different cultures, languages, literatures, genres, media and forms of communication. This time the by-word was the concept of "dialogue" which the participants interpreted variously as influence, reception, exchange, transition, translation, crossing genres and media. Intercultural encounters accompanying the recent movement of individuals and groups receive a variety of expressions and call for a debate in a transdisciplinary context. The conference was an occasion for many discussions on the broad subject of cultural neighbourhood, especially related to:

- minority cultures and literature, migration and narration, the Other

- autobiography and identity

- communication styles, pragmatics of intercultural communication

- communication in institutions

- folkloric communication, ethnolinguistics

- humour and irony in cultural context

- cross-cultural aspects of translation and (language) teaching

- English as an international lingua franca, language contacts

- culture and the teaching of languages, global learning, innovation in education

- contemporary culture and media, transnational/transmedial cultural texts, cultural and linguistic globalization

The Special Issue consists of 11 papers, which reflect the diversity of the conference. Several of these focus on theatre as a complex and multifaceted medium, 
particularly open to border crossings in practice as well as theoretical conceptualizations. In her paper, “The Director as Translator: The Case of Latvian Director Olǵerts Kroders", Vēsma Lēvalde discusses options and challenges for the theatre director's handwriting during the Soviet era, based on Olgerts Kroders' (1921-2012) two productions of Alexander Ostrovsky's “Without a Dowry”. Stage directing is also central to leva Rodina's discussion of more contemporary developments in Latvian theatre, "Blurring the borders between life and the theatre in the stage directing of Vladislavs Nastavševs". In her paper, "The Dynamics of Crossing Borders. The Case of Hella Wuolijoki [1886-1954]", A n neli Saro examines this Estonian writer's changing orientation to Finnish culture, where her plays and political writings are better received. In "Opera Across Borders: New Technologies and Mediatization", Lauma Mellēna-Bartkeviča approaches the challenges of inter- and transmedial reception situations for opera, and discusses the concept of "liveness" in the works of Paul Auslander and Bruce McConachie.

The thorny, often highly creative problematics of bilingualism is the topic of Irina Belobrovtseva's paper, "The Bilingual Writer", in which she comparatively examines the dynamics of this shift in the works of Estonian-Russian (Jaan Kaplinski, Kalle Käsper) and Russian-Estonian writers (Igor Kotjuh). In her paper, Aija Sakova focuses on the Estonian poet, critic, and literary statesman Ivar Ivask, whose many initiatives sought to disrupt the inward-looking restrictions of Estonian exile literature and situate Baltic literatures in a comparative European frame.

Two literary-historical articles direct the reader's attention to crossing temporal borders to analyse cultural phenomena in the more distant past. In his paper entitled "In Search of Grigory Skovoroda's Motivation”, Va dim Vozdvizhe nsky investigates the little-studied Hungarian period of the Ukrainian Christian writer and philosopher, Grigory Savvich Skovoroda (1722-1794). Ka irit Ka u r uses intricate archival retrieval and close analysis of texts to illuminate traces of British graveyard poetry in mid-19 ${ }^{\text {th }}$ century Baltic-German poetry belonging to the Toten$\operatorname{tanz}$ (Dance of Death) topos.

More recent topics are broached by Emrah Atasoy, whose article “Transformational Utopian/Dystopian Projections in Turkish Literature" argues for the broader recognition of the utopian mode of literature in Turkey, and the potential impact of utopian texts on social change, drawing on one of Adam Senel's texts, Teleandregenos Ütopyasında Evlilik Hayatı that has yet to be translated into larger languages. Dor ota Rygiel investigates hybridity in the dynamic process of constructing South Asian immigrant identities in post-World War II Britain through 
analysing main characters in Monica Ali's novel Brick Lane (2003) and Hanif Kureishi's novel The Buddha of Suburbia (1990).

The Special Issue closes with historian Ka arel Piirimä e's review of Ep p A n n u s' monograph, Soviet Postcolonial Studies: A View from the Western Borderlands (Routledge, 2018), and Epp Annus' response to the review. These two texts introduce a new discussion section to Methis, in which the author has a chance to enter into dialogue with the reviewer.

This Special Issue would not have been possible without the hard work and friendly advice of many colleagues both at Krosno State College and the Estonian Literary Museum. We are grateful for the thorough and constructive critique of our peer reviewers in Poland and Estonia, our ever alert and witty technical editor, Kanni Labi; English language editor and proofreader, Marika Liivamägi. Designer Krete Pajo was in charge of pouring out the Special Issue into elegant artistic format.

We are also grateful for the gracious financial subsidies of the University of Tartu Publications Fund, Stanistaw Pigoń State College in Krosno, and the Estonian Cultural Endowment. This Special Issue was supported by the institutional research grant "Formal and Informal Networks of Literature, Based on Sources of Cultural History" of the Estonian Ministry of Education and Research (IRG22-2), the Centre of Excellence in Estonian Studies (CEES, European Regional Development Fund), the Estonian Literary Museum and the University of Tartu.

Tiina Ann Kirss, Władystaw Witalisz, Marin Laak

Co-Editors of the Special Issue 